\title{
FEATURES OF SKIN WOUNDS HEALING UNDER CHRONIC HYPERGLYCEMIA AND IMPROVEMENT OF THEIR TREATMENT METHODS
}

DOI: $10.36740 /$ WLek202105124

\author{
Olena S. Maksymova, Svitlana M. German, Pavlo 0. Moskalenko, Viktoriia 0. Yasenok, Olena M. Gortynska, \\ Kyrylo M. Hortynskyi, Gennadii F. Tkach \\ SUMY STATE UNIVERSITY, SUMY, UKRAINE
}

\begin{abstract}
The aim: The work was aimed to study the histological, morphometric and planimetric features of skin regeneration in mature rats with chronic hyperglycemia under the influence of platelet-rich plasma.

Materials and methods: 60 mature white laboratory rats were used. The animals were divided into three groups (I - control with mechanical skin injuries; II - rats with chronic hyperglycemia and modeled mechanical skin injuries; III - animals with the chronic hyperglycemia and modeled mechanical skin injuries which were injected with the platelet-rich plasma). The samples were studied using light microscopy. Statistical data processing was performed using SPSS-17.

Results: $0 \mathrm{n}$ the 21st day, the epithelialization of control mature rats wound was almost complete. The epithelium contained all layers without pathological changes. The new dermis has been reorganized into papillary and reticular layers. On the 21st day, the wound of rats with chronic hyperglycemia was not completely covered with the epidermis. The connective tissue of the dermis was disorganized. On the 21st day, the wound epithelialization was also more complete in mature rats with chronic hyperglycemia received platelet-rich plasma compared to the rats with chronic hyperglycemia. The dermis contained a large number of blood vessels with normal, full-blooded lumens.

Conclusions: The chronic hyperglycemia leads to disruption of epithelialization processes, angiogenesis, a delay in the reorganization of dermis connective tissue, and vascular remodeling. The injections of autologous platelet-rich plasma promote faster angiogenesis, reduce inflammation, and accelerate wound epithelialization.
\end{abstract}

KEY WORDS: skin injury, chronic hyperglycemia, platelet-rich plasma, histology

Wiad Lek. 2021;74(5):1174-1179

\section{INTRODUCTION}

The reparative regeneration of organs and tissues under chronic hyperglycemia remains one of the most significant and understudied issues in medicine and biology [1]. Wound healing under chronic hyperglycemia $(\mathrm{CH})$ can be long-term relapsing in nature and hard to treat $[2,3]$. The observable increase in the number of people suffering from diabetes is the reason for classification the diabetes as a non-infectious pandemic [4].

Due to the scientific, clinical and economic significance, there have been a number of studies aimed on wound healing processes [5-8]. An active search for cost-effective methods that would improve and accelerate the regeneration of skin wounds has been continuing for today [9]. Earlier, it was reported that platelet-rich plasma (PRP) and a platelet concentrate promote better skin wound healing [10].

However, there are limited studies up to today regarding the study of effects of PRP on the skin wound healing processes in adults individuals with chronic hyperglycemia [11-13].

\section{THE AIM}

The work was aimed to study the histological, morphometric and planimetric features of skin regeneration in mature rats with chronic hyperglycemia under the influence of platelet-rich plasma.

\section{MATERIALS AND METHODS}

For the study, 60 male 7-9-months-mature white laboratory rats were used. The animals were divided into three groups. Control groups consisted of 20 mature rats (group I). Only mechanical skin injuries were modeled. Groups II included 20 mature rats, respectively, which were subjected to simulation of the chronic hyperglycemia and modeling of the mechanical skin injuries. Groups III also consisted of 20 mature rats, respectively, but along with the simulation of chronic hyperglycemia and the modeling of the mechanical skin injuries the animals were injected with the platelet-rich plasma.

The experimental animals were used according to the policies of general ethical principles of experiments on animals (Kyiv 2001), Declaration of Helsinki (2000), European Convention for the Protection of Vertebrate Animals used for Experimental and Other Scientific Purposes (Strasbourg 1985). Ethics and morality were not violated during the research. Rats were housed in the vivarium room under constant temperature $\left(24-25^{\circ} \mathrm{C}\right)$, 
humidity $(60 \pm 5) \%$, and 12-hour dark-light cycle. Cage cleaning was performed daily.

The chronic hyperglycemia in animals of groups II and III was modeled as previously described in $[14,15]$. On the 60th day after $\mathrm{CH}$ simulation, rats that have had a blood glucose level above $12 \mathrm{mmol} / \mathrm{l}$ for 3 consecutive days were selected for the study. Skin injury were modeled in animals of all groups. Prior to the surgery under aseptic conditions, animals were administered with intramuscularly xylazine $(3 \mathrm{mg} / \mathrm{kg})$ and after 5 minutes - ketamine $(8 \mathrm{mg} / \mathrm{kg})$ [14, 15]. Preoperative preparation of the surgical field was performed by shaving the skin in the interscapular area of the back and treating with $3 \%$ alcohol iodine solution. The wound was made by cutting a piece of skin with a diameter of $1.5 \mathrm{~cm}$ in the interscapular area of the back. In animals of groups I and II the wound was left to heal under the blood clot. Platelet-rich plasma was injected into the wound edges of rats of group III [16] which were prepared as previously described in $[14,15]$. The study of morphological and planimetric features of skin regeneration was performed on the 7th and 21st day after injury. At each time point, 10 rats from each group were sacrificed by the overdose with thiopental anesthesia ( $4 \mathrm{mg} / 100 \mathrm{~g}$ body weight).

In order to study the microscopic structure, the prepared areas of skin with a visible defect were fixed in $10 \%$ neutral formalin solution. After that, samples were prepared and processed as previously described in [14]. The planimetric analysis of the wound was performed by photographing of the injured area of skin with a microgrid immediately after the injury on the 7th and 21st day. The calculation of the wound surface area $\left(\mathrm{mm}^{2}\right)$ was performed using the universal Digimizer computing software (version 5.3.5). The wound healing rate in skin was calculated by the formula: $\mathrm{V}=\mathrm{S}_{0} / \mathrm{S}_{1}{ }^{*} \mathrm{t}\left(\mathrm{mm}^{2} /\right.$ day $), \mathrm{S}_{0}$ - the wound area at the previous measurement $\left(\mathrm{mm}^{2}\right) ; S_{1}$ - the wound area at a given measurement $\left(\mathrm{mm}^{2}\right) ; \mathrm{t}$ - the number of days between the first and the next measurement (day). The immunohistochemical assay was performed on the sections were incubated with primary CD34 monoclonal antibody (RM300, Thermo Fisher Scientific). The vascular density of the microcirculatory bloodstream in the regenerated skin was calculated by the positive membrane/submembrane reaction of the endothelium to $\mathrm{CD} 34$ on the entire section of the regenerated skin using the ImageJ2 program.

Statistical data processing was performed using SPSS- 17 (version 17.0, USA). Continuous data are presented as the arithmetic mean $(\mathrm{M})$ and the standard deviation (SD). The validation of normality of distribution was performed using the Kolmogorov-Smirnov criterion. The mean values between groups were compared by one-way analysis of variance (ANOVA) with subsequent a posteriori Bonferroni test. The difference was considered significant if the value of $\mathrm{P}$ did not exceed $0.05(\mathrm{P}<0.05)$.

\section{RESULTS}

On the 7th day of the study, the formation of granulation tissue, the beginning of epithelialization and the reduction of wound area were occurred in the wound of mature rats from the control group. Blood vessels had the defective walls and the hemorrhages were observed in the marginal areas of the regenerate. At this time point of the study, the complete epithelialization of the wound did not occur (Figure 1 (a)). On the 21st day, the wound epithelialization was almost complete. The epithelium contained all layers without pathological changes. The new dermis has been reorganized into papillary and reticular layers (Figure 1 (d)).

On the 7 th day of regeneration, the wound of mature rats with $\mathrm{CH}$ was filled with granulation tissue which contained the foci of inflammation. The blood vessels formed a chaotic network from all types simultaneously. The vascular walls were unstable, immature and did not have a full basement membrane. Due to the increased vascular wall permeability, the significant hemorrhages were occurred under the epidermis in the marginal areas of the wound (Figure 1 (b)). On the 21st day, the epithelialization was more complete than during the previous study period, but the wound was not completely covered with the epidermis. The epidermal basement membrane was incomplete, and, as a consequence, the keratinocytes penetrated into the connective tissue of dermis. The stratum granulosum contained concentric aggregates of keratin. Preserved cell nuclei and organelles were observed in the stratum corneum. The connective tissue of the dermis was disorganized (Figure $1(\mathrm{e})$ ).

On the 7th day of the experiment, the wound of mature rats with $\mathrm{CH}$ injected with PRP was filled with granulation tissue contained the foci of inflammatory infiltrate. No lipocytes and hemorrhages were found in the sections. The level of new epidermis growing into the wound center was higher than in rats with chronic hyperglycemia (Figure 1 (c)). On the 21st day, the wound epithelialization was also more complete in mature rats with $\mathrm{CH}$ received $\mathrm{PRP}$ compared to the rats with $\mathrm{CH}$. The dermis contained a large number of blood vessels with normal, full-blooded lumens. At this phase of the study, the complete reorganization of the dermis into papillary and reticular layers did not occur (Figure 1 (f)).

The results of statistical analysis on the 7th day after induced injury showed that the wound area was smaller by $31.78 \%(\mathrm{P}<0.001)$ in rats of the control group compared to the wound area in rats with $\mathrm{CH}$, and smaller by $17.89 \%(\mathrm{P}=0.015)$ compared to the rats with $\mathrm{CH}$ injected with PRP. On the 21st day after injury, the wound area in mature control rats was smaller by $96.81 \%(\mathrm{P}<0.001)$ compared to the animals with $\mathrm{CH}$ and smaller by $90.62 \%$ $(\mathrm{P}<0.001)$ compared to the animals with $\mathrm{CH}$ injected with PRP (Figure 2a).

On the 7th day after injury, the wound healing rate was lower by $74.88 \%(\mathrm{P}<0.001)$ in mature rats with $\mathrm{CH}$ than in control rats, but already on the 21st day, the wound healing rate was lower by $60.36 \%(\mathrm{P}<0.001)$ in rats of the control group than in rats with $\mathrm{CH}$. On the 7th day the wound healing rate was lower by $49.44 \%(\mathrm{P}<0,001)$ in mature rats with $\mathrm{CH}$ which received $\mathrm{PRP}$ injection compared to the control rats, but on the 21st day, conversely, the wound 
healing rate was lower by $50.75 \%(\mathrm{P}<0.001)$ in rats of the control group compared to the animals with $\mathrm{CH}$ which received PRP (Figure $2 b$ ).

On the 21st day after injury, the density of the microvasculature vessels in mature rats with $\mathrm{CH}$ was lower by $42.61 \%(\mathrm{P}<0.001)$ than in rats of the control group. However, a statistically significant difference was not found between the values of the vascular density in mature rats injected with PRP and the control group (Figure 3). Fig 3

\section{DISCUSSION}

The wound healing process under hyperglycemia is characterized by microcirculatory disorders, the microthrombus formation, the dystrophic and necrotic processes, the predominance of the inflammatory process over reparative, and the inhibition of cell proliferation [1, 11-13].

According to Dong et al, the disorder of wound regeneration in individuals with high blood glucose level is occurred at all stages of healing. This leads to the abnormal angiogenesis, persistent inflammation, inadequate formation of granulation tissue, reduced synthesis of collagen and glycosaminoglycans [11]. Efimov and Khoroshkevych have found that the skin regenerates of patients with diabetes have manifestations of parenchymal dysproteinosis and fatty degeneration, which reflects a violation of tissue metabolism in this category of patients and is a factor in the wound complications. A wound healing process in such patients is characterized by prolongation of the inflammatory phase and a delay of regenerative processes [12].

In our study, the reorganization of the dermis connective tissue was observed in mature rats of the control group on the 21st day. Furthermore, the hair follicles surrounded by sebaceous glands were found at this phase of the study and the wound epithelialization was almost reached completion. At the end of the experiment, the epithelialization of the wound was not reached completion in mature rats with $\mathrm{CH}$. The interruption of keratinization processes and a defective basement membrane were observed in the epithelium.

Ivanov et al. has found the complete healing of wound in all control animals by the 24th day of their experiment. They have also found the variability of wound healing rate in the group of rats with diabetes [17].

At the early stages of the current study, the wound healing rate and reduction of their areas in the control group was higher compared to the group with $\mathrm{CH}$. On the 21 st day, the wound healing rate increased in group with $\mathrm{CH}$ and, on the contrary, decreased in the control group. Herewith, the wound area of the control group was smaller among group with $\mathrm{CH}$.

Wound regeneration is a challenging healthcare problem since standard of care treatments are not always effective, which necessitates the development of the new prospective methods $[1,5,9]$. In this regard, the potential application of PRP in the treatment of patients with soft tissue injuries is of great interest [18].
In the studies on the structural features of the aseptic soft tissue wound healing, Glukhov et al. has found that on the 14th day the wound epithelialization was occurred with complete differentiation of cell layers of the epidermis when the platelet concentrate was used. By the 14th day of the study, the papillary and reticular layers of the dermis have already formed. The areas of large cellular infiltration were found in some samples thus indicating the residual effects of the inflammatory reaction. The rudiments of hair follicles and sebaceous glands were formed on the periphery of the regenerate. The signs of perivascular edema persisted around individual vessels [19].

In the current study, on the 21 st day the wound epithelialization occurred almost completely in mature rats injected with PRP.

Driver et al. has observed the formation of healthy granulation tissue and early complete healing of skin wounds in patients with diabetic foot ulcer under local application of PRP. They have noted a significant reduction in the size of the defect, no side effects, the reduced pain and inflammation at the site of injury in all patients who received PRP. Using experimental approaches, the researchers have demonstrated the accelerated healing of skin wounds after treatment with PRP and faster neovascularization of the affected area [20].

In the current study, the application of PRP in mature rats with $\mathrm{CH}$ led to the increased wound healing rate compared to animals that were not injected with PRP.

Also, it has been shown that while applying PRP the synthesis of type I collagen and matrix metalloproteinase and the maturation of granulation tissue are accelerated, the angiogenesis is enhanced, the scarring is reduced due to timely wound epithelialization and good organization of collagen fibers compared to wounds treated with traditional methods [21].

A day after the application of PRP, Lipova et al. has found the tendency to organize the structure of tissue, the appearance of mitosis of basal cells, fibroblasts, collagen fibers, which indicates the activation of regeneration processes. They have shown that the tissue structure was more organized on the 5th day and the columns of tightly packed basal cells have appeared. The epithelialization was observed on the wound edges. The number of fibroblasts and collagen bundles has increased, and there was angiogenesis started. After a day, no changes were observed in the group where traditional approaches of treatment were used. On the 5th day, angiogenesis was started but it was much less pronounced compared to the PRP groups. There was disorganization of collagen bundles noted [7]

By evaluating the processes of angiogenesis in sections of injured skin, it has been found that there was no significant difference in vascular density of the microcirculatory tract between the mature rats with $\mathrm{CH}$ injected with PRP and the control group of mature rats on the 21st day of the study.

According to the research of Aralova et al., on the 5th day the edema and hyperaemia were not observed in any group under the application of PRP. In the control group, the wound area was two times larger compared to the group injected with PRP [8]. 


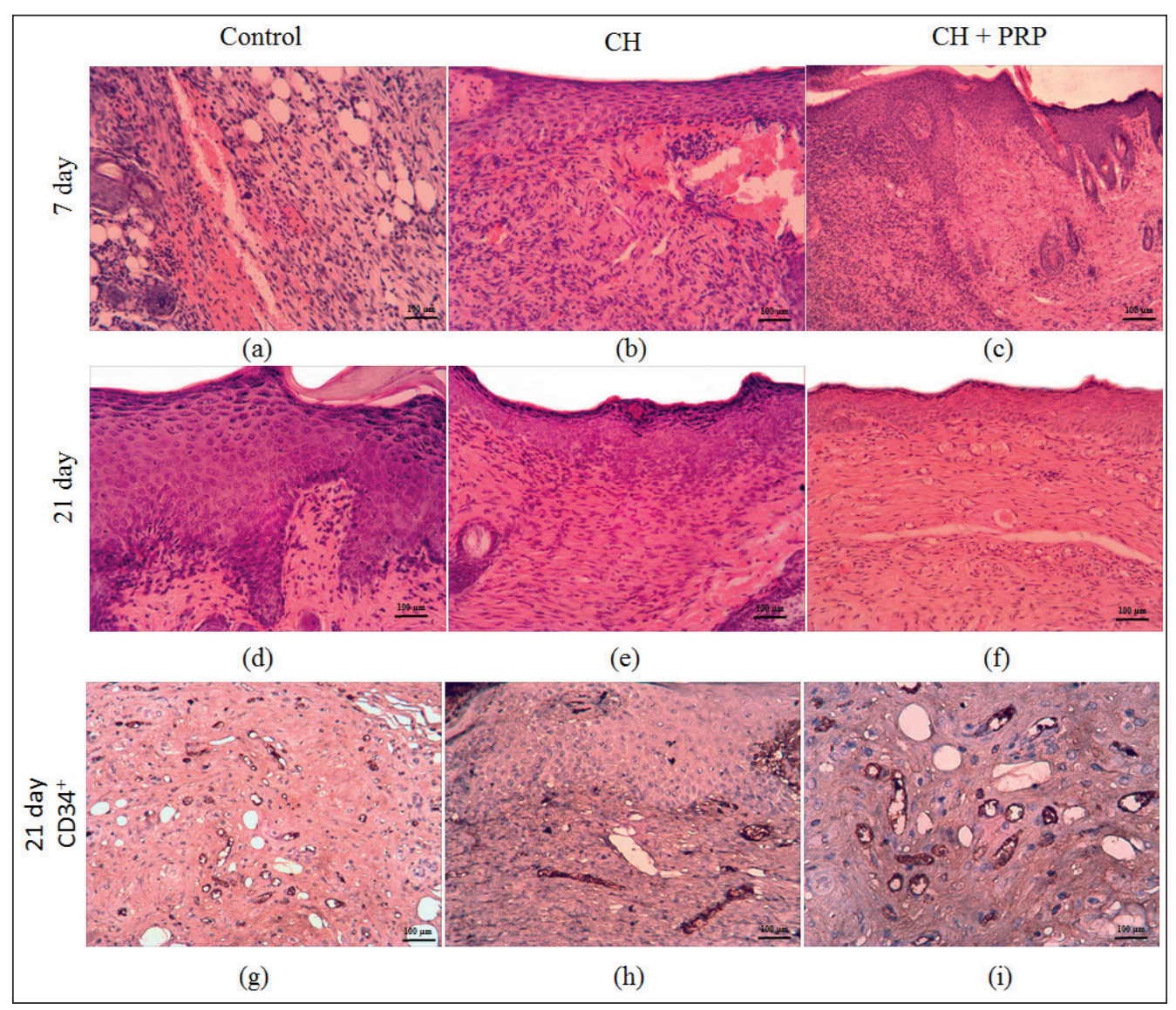

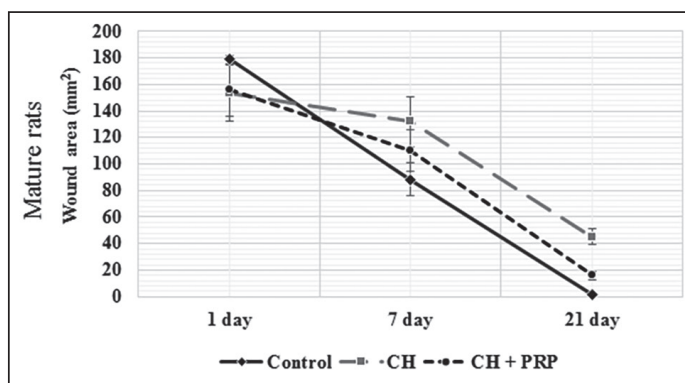

(a)

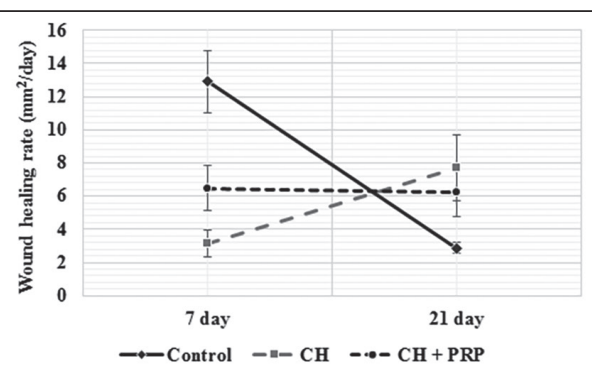

(b)

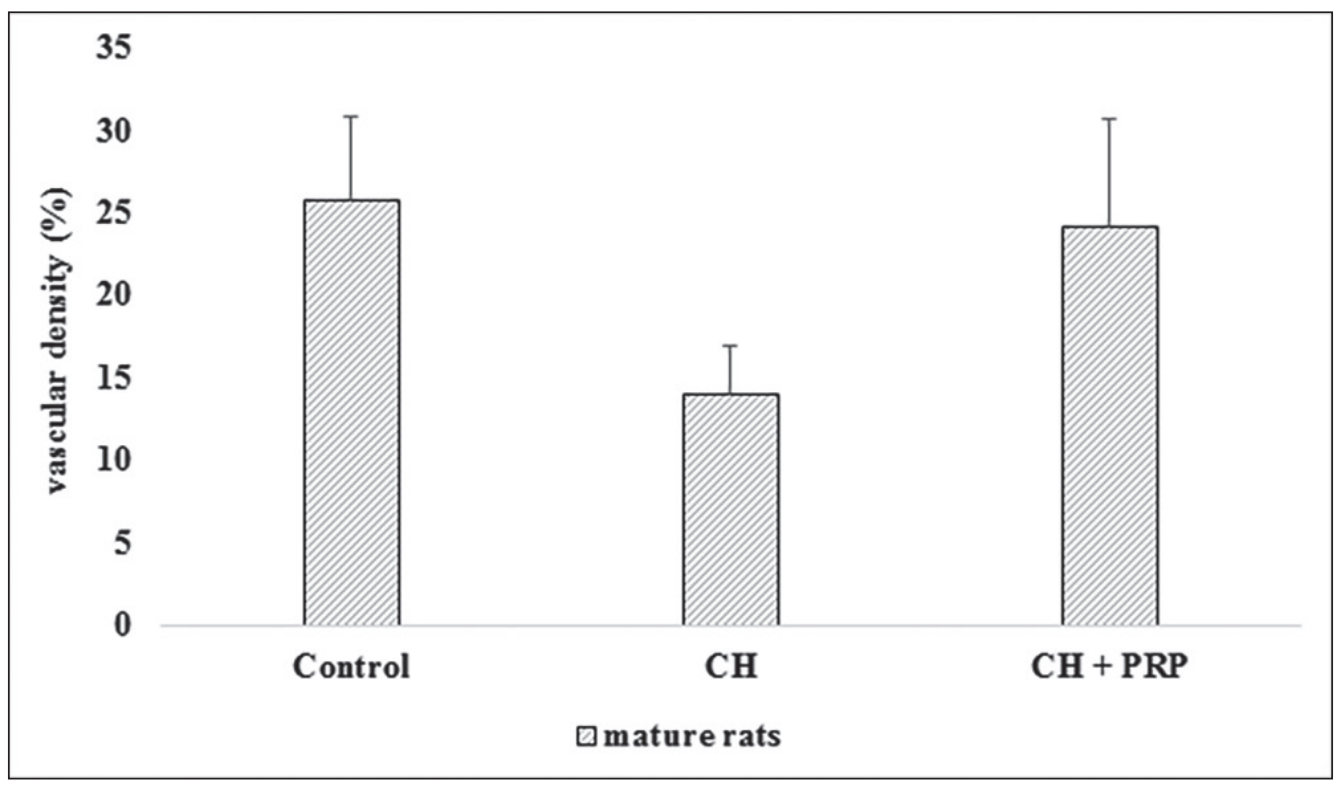

Fig. 1. Histology and immunohistochemistry of skin wound in mature rats: control $(a, d$, g), chronic hyperglycemia (b, $e, h)$, and chronic hyperglycemia+platelet-rich plasma $(c, f$, i) groups on the 7th and 21st day after mechanical injury. Explanations are in the text. Staining hematoxylin and eosin (a-f). Staining CD34 ( $g, h, i)$. Scale bar $100 \mu \mathrm{m}$

Fig. 2. The wound area (a) and wound healing $(b)$ rate of different groups on 1st, 7th and 21st days after mechanical injury. Data are presented as means \pm SD. CH: chronic hyperglycemia; PRP: platelet-rich plasma

Fig. 3. The vascular density in sections on the 21st day after modeled skin injury. Data are presented as means $\pm S D$. CH: chronic hyperglycemia; PRP: platelet-rich plasma. ${ }^{*}$ - Significant difference by ANOVA 
Thus, the results have showed that the application of PRP stimulates the skin wounds regeneration of various etiologies, which consists in the wound healing acceleration and regeneration its proper structure.

\section{CONCLUSIONS}

The chronic hyperglycemia leads to disruption of epithelialization processes, keratinization of the epidermis, angiogenesis, a delay in the reorganization of dermis connective tissue and vascular remodeling. The chronic hyperglycemia also causes the delayed wound healing. The injections of autologous PRP promote faster angiogenesis, reduce inflammation, and accelerate wound epithelialization.

\section{REFERENCES}

1. Perez-Zabala E., Basterretxea A., Larrazabal A. et al. Biological approach for the management of non-healing diabetic foot ulcers. J. Tissue Viability. 2016; 25(2):157-63. doi: 10.1016/j.jtv.2016.03.003.

2. OmelyanovskyV.V., Shestakova M.V., Avxentyeva M.V. etal. Ekonomycheskye aspekty sakharnogo dyabeta $v$ otechestvennoy praktyke [The economic aspects of diabetes mellitus in the national practice]. Medical technologies. Evaluation and selection. 2015;4:43-60. (in Russian).

3. Phillips A., Mehl A.A. Diabetes mellitus and the increased risk of foot injuries. JWound Care. 2015; 24(5):4-7. doi:10.12968/jowc.2015.24.Sup5b.4.

4. Whiting D.R., Guariguata L., Weil C. et al. IDF diabetes atlas: global estimates of the prevalence of diabetes for 2011 and 2030. Diabetes Res Clin Pract. 2011;94(3):311-21. doi: 10.1016/j.diabres.2011.10.029.

5. Suthar M., Gupta S., Bukhari S. et al. Treatment of chronic non-healing ulcers using autologous platelet rich plasma: a case series. J. Biomed. Sci. 2017;24(1):16. doi: 10.1186/s12929-017-0324-1.

6. Hersant B., SidAhmed-Mezi M., Bosc R. et al. Autologous plateletrich plasma/thrombin gel combined with split-thickness skin graft to manage postinfectious skin defects: a randomized controlled study. Adv. Skin Wound Care. 2017;30(11):502-8. doi: 10.1097/01. ASW.0000524399.74460.87.

7. Lipova E.V., Pokrovskii K.A., Gryazeva N.V. Opyt prymenenyya autologychnoy bogatoy trombotsytamy plazmy v lechenyy dlytelno nezazhyvayushchykh ran kozhy. [Use of autologous plateletrich plasma for the treatment of chronic cutaneous nonhealing wounds]. Annals of surgery. 2012;5:41-4. (in Russian).

8. Aralova M.V., Antakova L.N., Alimkina Yu.N. et al. Prymenenye obogashchennoy trombotsytamy plazmy v eksperymente. [Application of platelet-rich plasma in experiment]. Proceedings of Voronezh State University. Series: Chemistry. Biology. Pharmacy. 2019;2:72-9.

9. Nicoletti G., Saler M., Villani L. et al. Platelet rich plasma enhancement of skin regeneration in an ex-vivo human experimental model. Front Bioeng Biotechnol. 2019;7:2. doi:10.3389/fbioe.2019.00002.

10. Ahmad Z., Howard D., Brooks R.A. et al. The role of platelet rich plasma in musculoskeletal science. JRSM Short Rep. 2012;3:40. doi: 10.1258/ shorts.2011.011148.

11. Dong Y., Rodrigues M., Kwon S.H. et al. Acceleration of diabetic wound regeneration using an in situ-formed stem-cell-based skin substitute. Advanced Healthcare Materials. 2018; 7(17):1-9:e1800432. doi: 10.1002/adhm.201800432.

12. EfimovE.V., Khoroshkevich A.V. Osobennosty ranevogo protsessa na fone sakharnogo dyabeta. [Features of wound process affected by diabetes mellitus]. Wounds and wound infections. 2015;2(3):30-35. doi: 10.17 650 / 2408-9613-2015-2-3-30-35. (in Russian).
13. Troyanov A.A., Kondratenko G.G., Potapnev M.P. et al. Eksperymentalnoe y klynycheskoe obosnovanyeyspolzovanyya bogatoy trombotsytamy plazmy dlya lechenyya dolgo zazhyvayushchykh ran pry dyabete. [Experimental and clinical justification for the use of platelet-rich plasma to treat long-term healing wounds in diabetes]. Medical journal. 2018;2:112-17. (in Russian).

14. Rtail R., Maksymova 0., Illiashenko V. et al. Improvement of Skeletal Muscle Regeneration by Platelet-Rich Plasma in Rats with Experimental Chronic Hyperglycemia. BioMed Research International. 2020;6980607: 9. https://doi.org/10.1155/2020/6980607.

15. Dudchenko Y.S., Maksymova 0.S., Pikaliuk V.S. et al. Morphological Characteristics and Correction of Long Tubular Bone Regeneration under Chronic Hyperglycemia Influence. Analytical Cellular Pathology. 2020; 5472841: 7. https://doi.org/10.1155/2020/5472841.

16. Dionyssiou D., Demiri E., Foroglou P. et al. The effectiveness of intralesional injection of platelet-rich plasma in accelerating the healing of chronic ulcers: an experimental and clinical study. Int Wound J. 2012; 10(4): 397-406. doi: 10.1111/j.1742-481X.2012.00996.x.

17. Ivanov E.V., Morozova M.P., Rzhavina E.M. et al. Dyfferentsyatsyya keratynotsytov y zazhyvlenye rany v streptozototsynovoy modely sakharnogo dyabeta krysy s vyrazhennoy gyperglykemyey. [Keratinocytes differentiation and wound healing in rats with streptozotocin - induced diabetes and severe hyperglycemia]. Diabetes Mellitus. 2020;23(1):19-28. doi: 10.14341/DM10017. (in Russian).

18. Medvedev V.L., Kogan M.I., Mihailov I.V. et al. Autologychnaya plazma obogashchyonnaya trombotsytamy: chto eto y dlya chego? [Platelet-rich autologous plasma: what is it and for what?]. Urology Herald. 2020;8(2):6777. https://doi.org/10.21886/2308-6424-2020-8-2-67-77. (in Russian).

19. Glukhov A.A., Ostroushko A.P., Semenov S.N. et al. Strukturnofunktsyonalnye osobennosty zazhyvlenyya aseptycheskykh ran myagkykh tkaney pry yspolzovanyy obogashchennoy trombotsytamy plazmy krovy. [Structural and functional features of healing of aseptic wounds of soft tissues using by platelet-rich blood plasma]. Journal of experimental and clinical surgery. 2010;3(3):210-13. (in Russian).

20. Driver V.R., Hanft J., Fylling C.P. et al. Autologel diabetic foot ulcer study group. A prospective, randomized, controlled trial of autologous platelet-rich plasma gel for the treatment of diabetic foot ulcers. Ostomy Wound Manag. 2006;52(6):68-74.

21. Cho J.W., Kim S.A., Lee K.S. Platelet-rich plasma induces increased expression of $\mathrm{G} 1$ cell cycle regulators, type I collagen, and matrix metalloproteinase-1 in human skin fibroblasts. Int. J. Mol. Med. 2012;29(1): 32-6. doi: 10.3892/ijmm.2011.803.

The present study is the part of the scientific project "Morphofunctional aspects of organism homeostasis disturbance", supported by Ministry of Education and Science of Ukraine (no. 0118U006611).

\section{ORCID and contributionship:}

Olena S. Maksymova: 0000-0002-1470-1700 B,C,D

Svitlana M. German: 0000-0002-3996-2755 ${ }^{A}$

Pavlo O. Moskalenko: 0000-0003-3207-4146 ${ }^{B}$

Viktoriia O. Yasenok: 0000-0003-3250-2112 ${ }^{\mathrm{C}}$

Olena M. Gortynska: 0000-0003-1648-097X ${ }^{A}$

Kyrylo M. Hortynskyi: 0000-0002-6707-5651 ${ }^{B}$

Gennadii F. Tkach: 0000-0002-6482-4792 E,F

\section{Conflict of interest:}

The Authors declare no conflict of interest. 


\section{CORRESPONDING AUTHOR}

Olena S. Maksymova

Sumy state university

2 Rimsky-Korsakov St., 40000 Sumy, Ukraine

tel: +380 977863783

e-mail: alenamaksimova@ukr.net

Received: 28.11 .2020

Accepted: 01.04 .2021

A - Work concept and design, B - Data collection and analysis, C - Responsibility for statistical analysis,

$\mathbf{D}$-Writing the article, $\mathbf{E}$-Critical review, $\mathbf{F}$ - Final approval of the article 